\title{
Wpływ zaległości budżetowych na bezpieczeństwo finansowe budżetu państwa
}

\section{Influence of budget arrears on financial security of the state budget}

Streszczenie. Jedną z definicji bezpieczeństwa finansowego państwa jest zagrożenie finansowe związane ze ściągalnością dochodów budżetowych, tworzeniem się nadmiernych zaległości podatkowych w stosunku do dochodów budżetu państwa. W artykule poruszone zostały kwestie znacznego po 2012 r. przyrostu zaległości podatkowych. Poziom zaległości podatkowych wobec budżetu państwa ma charakter memoriałowy. Na wysoki poziom zaległości budżetowych istotny wpływ miało ograniczenie luki w VAT oraz poprawa skuteczności aparatu administracji skarbowej w ujawnianiu zobowiązań podatkowych. W artykule podnoszona jest mała efektywność działania organów egzekucyjnych w ściągalności zaległych zobowiązań podatkowych. Konsekwencją wysokiego poziomu zaległości wobec budżetu państwa jest negatywny wpływ na prowadzenie działalności gospodarczej zalegających z płatnościami wobec budżetu państwa. 
Słowa kluczowe: bezpieczeństwo finansowe państwa; zobowiązanie podatkowe; zaległość podatkowa; luka w podatku od towarów i usług; forma dochodzenia zaległości.

\begin{abstract}
Financial security of a state can be defined in a number of ways. Among others, it can be defined as a direct relation with a financial threat connected with the budget revenue collection. To put it in other words - a financial security of a state can be understood as an accumulation of excessive tax arrears compared to state budget revenues. This paper discusses a significant increment in tax arrears, which have been noted after 2012. The level of tax arrears in comparison with the state budget is of a memorial nature. The tightening of the VAT loophole and an improvement in the effectiveness of the tax administration machine in revealing tax liabilities strongly influenced high budget arrears. This paper points out the low efficiency of tax arrears collection by enforcement bodies. The high level of the arrears in comparison with the state budget negatively impacts businesses run by those who are behind payments which are due to the state budget.
\end{abstract}

Keywords: state financial security; tax liability; tax arrears; loophole in the tax on goods and services; form of seeking arrears.

\title{
1. Wprowadzenie
}

Bezpieczeństwo finansowe nie zostało dotychczas precyzyjnie zdefiniowane w literaturze przedmiotu. Autorzy opracowań naukowych albo rezygnują z definiowania tego pojęcia, albo odnoszą je do kwestii systemu finansowego państwa. Bezpieczeństwo finansowe państwa to zdolność do pozyskania środków pieniężnych w sytuacji, gdy zachodzi taka potrzeba. Jest to stan (niezagrożenia), który daje poczucie pewności funkcjonowania podmiotu oraz szansę na jego rozwój. Bezpieczeństwo finansowe rozumiane jest również jako stan pośredni w budowaniu niezależności finansowej państwa. Istotny wpływ na bezpieczeństwo finansowe państwa ma równomierny dopływ środków budżetowych zabezpieczających realizację zadań publicznych.

W ramach bezpieczeństwa finansowego państwa można wyróżnić zagrożenie finansowe związane ze ściągalnością dochodów budżetowych, 
tworzeniem się nadmiernych zaległości podatkowych w stosunku do dochodów budżetu państwa. Zaległości podatkowe ograniczają możliwości realizacji zadań publicznych. System finansów publicznych, a zwłaszcza prawo podatkowe, są ściśle związane z polityką finansową, która jest odbiciem polityki społeczno-ekonomicznej państwa, realizuje jej podstawowe cele ${ }^{1}$. Ze względu na zakres działania oraz metody w ramach polityki finansowej można wyróżnić politykę fiskalną, politykę podatkową i wspólny ich cel - dostarczanie środków finansujących dobra i usługi publiczne oraz wspierające rozwój gospodarki realnej realizacji celów społecznych. Nie przystaje do obecnych warunków teza Z. Fedorowicza, iż „ogólną tendencją jest eliminacja wykorzystania systemu podatkowego do realizacji celów polityki społecznej w Polsce”2 ${ }^{2}$ Przeciwnicy gospodarczych funkcji państwa twierdzą, że państwo zawsze gorzej realizuje takie zdania i proponują powierzenie budowy i utrzymanie inwestycji produkcyjnych (drogowych) sektorowi prywatnemu. Dotychczasowe polskie doświadczenia wykazują jednak, że sektor prywatny wcale lepiej nie realizuje tych zadań i jest dla społeczeństwa kosztowniejszy (np. budowa autostrad i korzystanie z nich).

Celem artykułu jest przeprowadzenie analizy realizacji dochodów budżetu państwa oraz wskazanie konsekwencji tego zjawiska w kontekście utrzymania stabilności budżetu państwa. Stwierdzić jednak należy, że ocena rzeczywistych rozmiarów zaległości jest trudna. Jest ona pochodną rozmiarów produktu krajowego brutto i wzrostu dochodów budżetowych.

Odnosząc się do pojęcia bezpieczeństwa finansowego państwa, można je definiować jako ogół regulacji prawnych oraz samoregulacji mających na celu zapewnienie stabilności finansowej oraz ochronę interesów uczestników rynku korzystających z usług pośredników finansowych,

1 M. Ślifirczyk, Ogólne materialne prawo podatkowe, [w:] M. Bitner, E. Chojna-Duch, M. Grzybowski, J. Chowaniec, P. Karwat, E. Kornberger-Sokołowska, M. Lachowicz, H. Litwińczuk, W. Modzelewski, K. Radzikowski, M. Supera-Markowska, M. Ślifirczyk, K. Tetłak, M. Waluga, Prawo finansowe. Prawo finansów publicznych. Prawo podatkowe. Prawo bankowe, Warszawa 2017, s. 97.

2 Z. Fedorowicz, Finanse publiczne, [w:] J. Ostaszewski (red.), Finanse, Warszawa 2008, s. 119. 
a także ogół instytucji odpowiadających za kontrolę przestrzegania tych regulacji i samoregulacji. W jeszcze innym ujęciu jest to zespół rozwiązań instytucjonalnych i regulacji prawnych, mających na celu ochronę systemu finansowego przed destabilizacją. Bezpieczeństwo finansowe według tego ujęcia związane jest z koniecznością prowadzenia działań o charakterze stabilizacji finansowej. Wysiłek państwa w celu pozyskiwania dochodów ma charakter wybitnie administracyjny, a nie ekonomiczny, a ryzyko związane z aktywnością państwa w tej dziedzinie nie jest analogiczne do ryzyka ponoszonego przez podatnika.

Waga i aktualność podjętej w niniejszym artykule problematyki bezpieczeństwa finansowego państwa wynika przede wszystkim z powszechności i trwałości zjawiska zaległości budżetowych, których rozmiary w ostatnim okresie przybierają dość niepokojące rozmiary.

Bezpieczeństwo ekonomiczne, do którego zaliczyć należy bezpieczeństwo finansowe, oznacza taki stan ustroju politycznego i będącego jego następstwem systemu gospodarczego, który zapewnia swobodę prowadzenia działalności podmiotom gospodarczym, stabilizację warunków makroekonomicznych prowadzenia tej działalności, względnie niskie obciążenia biurokratyczne i podatkowe, na tyle uregulowane stosunki międzynarodowej wymiany, aby zapewnić porównywalne warunki konkurencji oraz udziału w międzynarodowych sojuszach zwiększających względną odporność na negatywne oddziaływanie otoczenia zewnętrznego.

Jednym z najpopularniejszych kryteriów klasyfikacji w ramach bezpieczeństwa ekonomicznego państwa jest obszar bezpieczeństwa finansowego. Najprościej bezpieczeństwo można zdefiniować jako stan, w którym nie ma zagrożeń. Jest to definicja uniwersalna, gdyż dotyczy sporej grupy zagrożeń, jakie mogą destabilizować politykę czy gospodarkę danego kraju. Z kolei najczęściej mianem bezpieczeństwa finansowego państwa określa się stan braku zagrożeń w sferze finansów publicznych. To zdolność do pozyskania środków pieniężnych w sytuacji, gdy zachodzi taka potrzeba. Jest to również stan braku zagrożenia, który daje poczucie pewności funkcjonowania danego podmiotu oraz szansę na jego rozwój. 
O bezpieczeństwie finansowym danego państwa decydują przede wszystkim czynniki takie jak: stabilność i suwerenność systemu finansowego ${ }^{3}$.

W opracowaniu postawiono hipotezę, że wzrost dochodów budżetowych oraz działania na rzecz optymalizacji podatków ma znaczący wpływ na rozmiar zaległości budżetowych. Zaległości budżetowe mają jednak negatywny wpływ na procesy gospodarcze oraz wprowadzają zakłócenia w stabilności dochodów budżetu państwa.

\section{Zobowiązanie podatkowe w rozumieniu prawa podatkowego}

Jak na wstępie wspomniano, część składową bezpieczeństwa finansowego państwa stanowi bezpieczeństwo finansów publicznych, jednym z głównych symptomów zakłócenia bezpieczeństwa finansów publicznych jest nierównowaga fiskalna skutkująca narastaniem długu publicznego. W analizowanym artykule chodzi o skutki wzrostu zaległości budżetowych dla budżetu państwa.

Zobowiązanie podatkowe jako dług w stosunku zobowiązania podatkowego precyzuje świadczenie (czyli określone zachowanie), jakie powinno zostać wykonane. Jak z tego wynika, prawna regulacja zobowiązania podatkowego wymaga wskazania nie tylko kwoty podatku, lecz również terminu i miejsca, w który płatność powinna nastąpić. Dla jednostki podatki są „ceną”, „kosztem” dobra lub usługi dostarczanej przez rząd w celu zaspokojenia pewnych potrzeb ${ }^{4}$. Pojęcie podatku zostało ustawowo zdefiniowane w art. 6 ustawy z dnia 29 sierpnia 1997 r. - Ordynacja podatkowa $^{5}$. Zgodnie $\mathrm{z}$ powołanym przepisem podatkiem jest publicznoprawne, nieodpłatne, przymusowe oraz bezzwrotne świadczenie pieniężne na rzecz Skarbu Państwa, województwa, powiatu lub gminy. Z kolei ogólne zasady dotyczące terminu płatności podatku zostały określone w Ordynacji podatkowej. Zgodnie z nimi termin płatności podatku jest

\footnotetext{
3 M. Redo, K. Wójtowicz, J.M. Ciak, Bezpieczeństwo finansów publicznych, Warszawa 2018, s. 19.

J.M. Buchanan, Finanse publiczne w warunkach demokracji, Warszawa 1997, s. 123-124.

Dz.U. z 2017 r., poz. 201 ze zm.
} 
ustalany odmiennie w zależności od tego, czy zobowiązanie podatkowe powstaje przez doręczenie decyzji ustalającej, czy też z mocy prawa.

Zgodnie z art. $51 \S 1$ Ordynacji podatkowej podatek niezapłacony w terminie płatności staje się zaległością podatkową. Zaległość taka pojawia się również w wyniku niezapłacenia w terminie zaliczki na podatek lub raty podatku. Ustawodawca zrównał ponadto sytuację, w której istnieje zaległość podatkowa, niektóre przypadki, w których dłużnik podatkowy stał się beneficjentem nienależnego świadczenia o charakterze podatkowym, np. nadpłaty podatku lub zwrotu podatku. Konsekwencją powstania zaległości podatkowej jest obowiązek naliczenia od niej i uiszczenia odsetek za zwłokę. Odsetki za zwłokę co do zasady nalicza dłużnik podatkowy i wpłaca bez wezwania do organu podatkowego. W przypadku korzystania przez podatnika z ulg w spłacie zobowiązań podatkowych polegających na odroczeniu terminu płatności lub rozłożeniu należności na raty podatnik jest zobowiązany do uiszczenia opłaty prolongacyjnej. Przepisy te stosuje się również do nieuregulowanych w terminie zaliczek na podatek w części przekraczającej wysokość podatku należnego za okres rozliczeniowy.

Instytucje te na mocy Ordynacji podatkowej mają odpowiednie zastosowanie do należności, jakie na rzecz organu podatkowego reprezentującego budżet państwa powinny być regulowane również przez płatnika, inkasenta lub osobę trzecią odpowiadającą za zaległości podatkowe. Konkludując, stwierdzić należy, iż długiem z tytułu podatków przestaje być powinność uiszczenia kwoty podatku, a staje się nim powinność zapłaty kwoty zaległości podatkowej i ewentualnych odsetek za zwłokę. W tabeli 1 przedstawiono wielkość zaległości podatkowych na tle produktu krajowego brutto i dochodów budżetu państwa w latach 2010-2016. 
Wpływ zaległości budżetowych na bezpieczeństwo...

Tabela 1. Produkt krajowy brutto, dochody budżetu państwa i zaległości wobec budżetu państwa w latach 2010-2016.

\begin{tabular}{|l|r|r|r|r|r|r|r|}
\hline \multirow{2}{*}{ Wyszczególnienie } & \multicolumn{7}{|c|}{ Lata } \\
\cline { 2 - 8 } & $\mathbf{2 0 1 0}$ & \multicolumn{1}{|c|}{$\mathbf{2 0 1 1}$} & \multicolumn{1}{|c|}{$\mathbf{2 0 1 2}$} & \multicolumn{1}{c|}{$\mathbf{2 0 1 3}$} & \multicolumn{1}{c|}{$\mathbf{2 0 1 4}$} & \multicolumn{1}{c|}{$\mathbf{2 0 1 5}$} \\
\hline $\begin{array}{l}\text { Produkt Krajowy } \\
\text { Brutto (w mln zł) }\end{array}$ & 1445297 & 1566813 & 1629392 & 1656842 & 1719704 & 1798302 & 1851200 \\
\hline $\begin{array}{l}\text { dynamika PKB } \\
\text { (rok poprzedni - } \\
100 \% \text { \%) }\end{array}$ & 107,6 & 108,4 & 104,0 & 101,7 & 103,8 & 104,6 & 102,9 \\
\hline $\begin{array}{l}\text { dochody budżetu } \\
\text { państwa } \\
\text { (w mln zł) }\end{array}$ & 250302,8 & 277557,2 & 287585,1 & 279141,2 & 283542,7 & 289136,7 & 314683,6 \\
\hline $\begin{array}{l}\text { zaległości wobec } \\
\text { budżetu państwa } \\
\text { (w mln zł) }\end{array}$ & 23138,2 & 25895,0 & 30076,6 & 36078,6 & 45373,0 & 64712,4 & 85455,1 \\
\hline $\begin{array}{l}\text { udział zaległości } \\
\text { w dochodach } \\
\text { budżetu państwa } \\
\text { (w \%) }\end{array}$ & 9,2 & 9,3 & 10,5 & 12,9 & 16,0 & 22,4 & 27,2 \\
\hline $\begin{array}{l}\text { dynamika docho- } \\
\text { dów budżetu } \\
\text { państwa (w \%) }\end{array}$ & 91,3 & 110,9 & 103,6 & 97,2 & 101,6 & 102,0 & 108,8 \\
\hline $\begin{array}{l}\text { dynamika zaległo- } \\
\text { ści budżetu pań- } \\
\text { stwa (w \%) }\end{array}$ & 108,8 & 110,9 & 116,1 & 119,9 & 125,8 & 142,6 & 132,1 \\
\hline
\end{tabular}

Źródło: Opracowanie własne na podstawie danych: Główny Urząd Statystyczny, Zweryfikowany szacunek produktu krajowego brutto za lata 2010-2015, Warszawa 19.10.2016 r., stat.gov.pl; Ministerstwo Finansów, Sprawozdanie z wykonania budżetu państwa (roczne) za lata 2009-2016, www.mf.gov.pl.

Dane wskazują, że w latach 2010-2016 udział zaległości budżetowych w dochodach budżetu państwa kształtował się na zróżnicowanym poziomie. W latach 2010-2012 wielkość ta kształtowała się na poziomie ok. 10\%, zaś od 2013 r. poziom ten zaczął rosnąć i w 2016 r. relacja zaległości budżetowych do dochodów budżetu państwa wzrosła do poziomu 27,2\%. Dynamika zaległości budżetowych była wyższa w stosunku do dynamiki produktu krajowego brutto. Znaczący przyrost zaległości budżetowych nastąpił w roku $2016 \mathrm{w}$ stosunku do roku 2010, tj. 62 316,9 
mln zł. Ponadto dynamika wzrostu dochodów budżetu państwa znacznie odbiegała od dynamiki zaległości budżetowych. W 2010 r. różnica ta wynosiła 9,5 pkt proc., zaś w 2016 r. 23,3 pkt proc.

Wzrost dochodów budżetowych świadczy o sprawności aparatu fiskalnego w ujawnianiu przestępczości podatkowej. Na wzrost skuteczności organów podatkowych w ujawnianiu przestępczości ma również wpływ wprowadzenie wysokich kar za przestępstwa podatkowe.

W latach 2011-2012 ujawniła się tzw. luka podatkowa w podatku od towarów i usług. Po pierwsze jako pokłosie kryzysu, a po drugie to oszustwa podatkowe, a także zwykłe błędy w deklaracjach, legalna optymalizacja podatkowa, szara strefa oraz - najważniejsze- to bankructwa i upadłości. W 2016 r. luka podatkowa była wyższa niż w 2015 r. Zgodnie z danymi wiodącej globalnej organizacji świadczącej usługi doradcze PwC wzrosła ona z 2,8 proc. PKB w 2015 r. do 2,9 proc. PKB w 2016 r. Luka w VAT stanowiła ok. 30\% wpływów z VAT ${ }^{6}$.

\section{Zaległości podatkowe zagrożeniem bezpieczeństwa finansowego budżetu państwa}

Jednym z elementów bezpieczeństwa rozpatrywanego z przedmiotowego punktu widzenia, a w szczególności z punktu referowanego tematu, jest bezpieczeństwo finansowe, a konkretnie w jego ramach wpływ zaległości podatkowych na bezpieczeństwo budżetu państwa. Pojęcie bezpieczeństwa finansowego nie zostało jeszcze dokładnie zdefiniowane. Jest ono elementem bezpieczeństwa ekonomicznego państwa. Definicja bezpieczeństwa finansowego prezentowana przez R. Wierzbę to zespół rozwiązań instytucjonalnych i regulacji prawnych, mających na celu ochronę systemu finansowego przed destabilizacją ${ }^{7}$.

6 Zakładając, że luka podatkowa w VAT w Polsce stanowi nadal ok. 32\% dochodów z VAT, oznacza to, że wpływy z VAT w 2016 r. sięgnęły 126,6 mld PLN, a mogły być o 40 mld PLN wyższe, co oznaczało, że wysoki ich poziom przekładał się na przyrost zaległości budżetowych, PwC, Luka podatkowa VAT w Polsce, Informacja z 23.11.2016 r., www.pwc.pl.

7 R. Wierzba, System gwarantowania depozytów jako element sieci bezpieczeństwa finansowego. Doświadczenia francuskie, „Bezpieczny Bank” 2005, nr 1, s. 38. 
Administracja podatkowa nie może odmówić pobrania podatku, chociaż może odmówić dokonania wydatku. Kompetencje administracji są również ograniczone w zakresie formy poboru podatków na rzecz budżetu państwa ${ }^{8}$.

W latach 2010-2016 udział procentowy zaległości budżetowych w dochodach budżetu państwa kształtował się odpowiednio: 9,2\%; 9,3\%; 10,5\%; 12,9\%; 16,0\%; 22,4\% i 27,2\%.

Stan zaległości na 30 czerwca 2017 r. wyniósł 96 021,6 mld zł i udział w dochodach budżetu państwa stanowił 27,4\%. Wzrost na 30 czerwca 2017 r. w stosunku do 2010 r. wyniósł 72883,4 mld zł (wzrost o 18,2 pkt proc. $)^{9}$. Z danych tabeli 2 wynika, iż największy poziom zaległości kształtował się w podatku od towarów i usług, którego udział w strukturze zaległości ogółem stanowił w 2010 r. 50,17\%, zaś w 2016 r. wyniósł 76,4\%. Jedną z przyczyn tak wysokiej dynamiki w tym podatku oraz wysoki poziom jego udziału w strukturze zaległości ogółem może być wysoka stawka tego podatku wprowadzona z dniem 1 stycznia 2011 roku (stawka 23\%). Z kolei udział zaległości w podatku dochodowym od osób prawnych i w podatku dochodowym od osób fizycznych kształtował się na koniec 2010 r. i na koniec 2015 r. odpowiednio: 4,80\% i 4,97\% oraz 4,9\% i 8,3\% w zaległościach ogółem.

Wskazać należy, iż zaległości w podatkach bezpośrednio przekładają się na obniżenie dochodów budżetu jednostek samorządu terytorialnego z tytułu udziału w tych podatkach, zaś wzrost zaległości w podatkach pośrednich i pozostałych tytułach podatkowych ogranicza w sposób istotny możliwości realizacji zadań budżetu państwa i zabezpieczenia odpowiedniego poziomu dotacji i subwencji dla tych jednostek.

P.M. Gaudemet, J. Molinier, Finanse publiczne, Warszawa, 2000, s. 400-401.

Ministerstwo Finansów, Informacja o kształtowaniu się zaległości budżetowych wg stanu na 30.06.2017 r., www.mf.gov.pl. 
Władysław Grześkiewicz

Tabela 2. Poziom zaległości budżetowych w latach 2010-2016 (w mln zł).

\begin{tabular}{|c|c|c|c|c|c|c|c|}
\hline \multirow{2}{*}{ Wyszczególnienie } & \multicolumn{7}{|c|}{ Lata } \\
\hline & 2010 & 2011 & 2012 & 2013 & 2014 & 2015 & 2016 \\
\hline $\begin{array}{l}\text { Zaległości ogółem, } \\
\text { w tym: }\end{array}$ & 23138,2 & 25895,0 & 30076,6 & 36078,6 & 45373,0 & 64712,4 & 85455,1 \\
\hline $\begin{array}{l}\text { podatek dochodo- } \\
\text { wy od osób praw- } \\
\text { nych }\end{array}$ & 1112,2 & 1257,0 & 1278,4 & 1883,8 & 2 190,0 & 2882,6 & 4238,0 \\
\hline $\begin{array}{l}\text { podatek dochodo- } \\
\text { wy od osób fizycz- } \\
\text { nych }\end{array}$ & 4072,3 & 4530,2 & 5308,9 & 6002,9 & 6425,8 & 6776,8 & 7077,7 \\
\hline $\begin{array}{l}\text { podatek od towa- } \\
\text { rów i usług }\end{array}$ & 11609,3 & 13309,1 & 16404,9 & 20972,0 & 29768,0 & 46214,2 & 65253,2 \\
\hline podatek akcyzowy & 5595,2 & 6156,6 & 6485,8 & 6642,2 & 6440,8 & 8458,1 & 8507,1 \\
\hline podatek od gier & 41,5 & 54,105 & 60,7 & 80,7 & 77,9 & 81,5 & 85,9 \\
\hline podatki zniesione & 23,9 & 19,3 & 15,7 & 14,4 & 12,6 & 8,3 & 6,8 \\
\hline cła & 561,0 & 535,1 & 481,8 & 418,5 & 337,3 & 291,0 & 286,4 \\
\hline $\begin{array}{l}\text { grzywny, } \\
\text { mandaty }\end{array}$ & 22,4 & 33,6 & 40,5 & 64,3 & 120,7 & - & - \\
\hline $\begin{array}{l}\text { opłata restruktury- } \\
\text { zacyjna }\end{array}$ & 0,3 & 0,0 & 0,009 & 0,009 & 0,004 & - & - \\
\hline
\end{tabular}

Źródło: Opracowanie własne na podstawie danych: Ministerstwo Finansów, Informacja o kształtowaniu się zaległości budżetowych za poszczególne lata, www.mf.gov.pl.

Z tabeli 2 wynika, że lata 2010-2016 charakteryzowały się systematycznym przyrostem zaległości budżetowych. Istotny przyrost zaległości budżetowych ogółem nastąpił po 2012 r. Przyrost zaległości w 2016 r. w stosunku do 2010 r. wyniósł aż 369,32\%. Stwierdzić należy, iż w dalszym ciągu dynamicznie rosły zaległości podatkowe, które stanowiły w 2016 r. 79,2\% ogółem zaległości budżetu państwa. Zaległości z tytułu podatków wzrosły o 30,2\% i według stanu na 31 grudnia 2016 r. wyniosły 76,8 mld zł. Najwięcej, bo prawie 78\%, zaległości podatkowych stanowiły zaległości z tytułu podatku od towarów i usług. Były to kwoty wymierzone w znacznej mierze podmiotom, które już na etapie postępowania kontrolnego nie miały majątku ani środków na rachunkach bankowych.

Postępowanie egzekucyjne prowadzone wobec podmiotów dokonujących oszustw podatkowych, w tym z wykorzystaniem faktur dokumen- 
tujących czynności fikcyjne, były mało skuteczne ${ }^{10}$. Decydujący wpływ na rozmiary należności miały kwoty wymierzone w wyniku wykrycia istotnych nieprawidłowości przez organy kontroli skarbowej i organy podatkowe, istnienia tzw. luki VAT, stanowiącej różnicę pomiędzy faktycznymi wpływami z tytułu VAT do budżetu państwa a tymi, jakie teoretycznie powinny wpłynąć zgodnie z obowiązującymi rozwiązaniami podatkowymi.

Tabela 3. Struktura zaległości budżetowych w latach 2010-2016 (w \%).

\begin{tabular}{|l|r|r|r|r|r|r|r|}
\hline \multirow{2}{*}{ Wyszczególnienie } & \multicolumn{7}{|c|}{ Lata } \\
\cline { 2 - 8 } & $\mathbf{2 0 1 0}$ & $\mathbf{2 0 1 1}$ & $\mathbf{2 0 1 2}$ & $\mathbf{2 0 1 3}$ & $\mathbf{2 0 1 4}$ & $\mathbf{2 0 1 5}$ & $\mathbf{2 0 1 6}$ \\
\hline $\begin{array}{l}\text { Zaległości ogółem, } \\
\text { w tym: }\end{array}$ & 100 & 100 & 100 & 100 & 100 & 100 & 100 \\
\hline $\begin{array}{l}\text { podatek dochodowy od } \\
\text { osób prawnych }\end{array}$ & 4,8 & 4,8 & 4,2 & 5,2 & 4,8 & 4,4 & 4,9 \\
\hline $\begin{array}{l}\text { podatek dochodowy od } \\
\text { osób fizycznych }\end{array}$ & 17,5 & 17,5 & 17,6 & 16,6 & 14,2 & 10,4 & 8,2 \\
\hline $\begin{array}{l}\text { podatek od towarów } \\
\text { i usług }\end{array}$ & 50,1 & 51,4 & 54,4 & 52,1 & 65,6 & 71,4 & 76,3 \\
\hline podatek akcyzowy & 24,1 & 23,8 & 21,6 & 18,4 & 14,2 & 13,1 & 9,9 \\
\hline podatek od gier & 0,2 & 0,2 & 0,2 & 0,2 & 0,2 & 0,1 & 0,1 \\
\hline podatki zniesione & 0,1 & 0,1 & 0,0 & 0,0 & 0,0 & 0,0 & 0,0 \\
\hline cła & 2,4 & 2,1 & 1,6 & 1,2 & 0,7 & 0,4 & 0,3 \\
\hline grzywny, mandaty & 0,0 & 0,1 & 0,1 & 0,2 & 0,2 & - & - \\
\hline opłata restrukturyzacyjna & 0,0 & 0,0 & 0,0 & 0,0 & 0,0 & - & - \\
\hline
\end{tabular}

Źródło: Opracowanie własne na podstawie danych z tabeli 2.

Z analizy danych tabeli 3 wynika, że struktura zaległości w roku 2016 w stosunku do roku wyjściowego (2010) uległa daleko idącym zmianom (wykres 1 i 2).

10 Zob. Najwyższa Izba Kontroli, Analiza wykonania budżetu państwa i założeń polityki pieniężnej w 2016 roku, s. 13, www.nik.gov.pl. 
Władysław Grześkiewicz

Wykres 1. Struktura zaległości budżetowych w 2010 r.

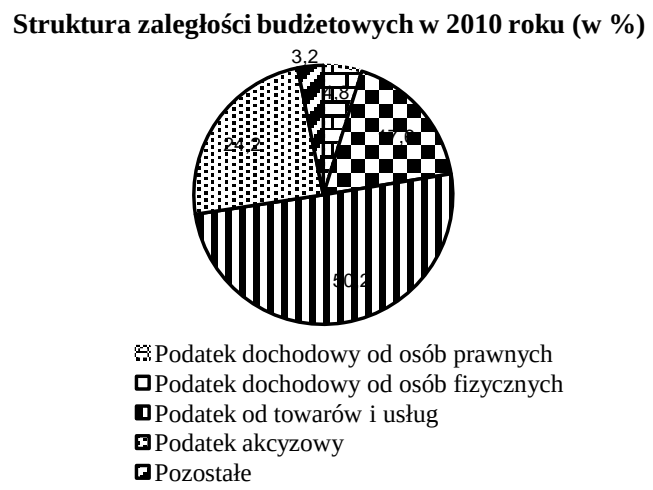

Źródło: Opracowane własne na podstawie danych tabeli 3.

Największa różnica we wzroście zaległości wystąpiła w podatku VAT (20,2 pkt proc.), a w następnej kolejności nieznaczny wzrost nastąpił tylko w podatku dochodowym od osób prawnych (0,2 pkt proc.) w pozostałych tytułach danin publicznych nastało obniżenie wielkości podatków w strukturze zaległości budżetowych. Najwyższy spadek wystąpił w podatku akcyzowym (14,3 pkt proc.) i w podatku dochodowym od osób fizycznych (9,3 pkt proc.). Stan ten jest wynikiem zmian w przyroście zaległości w poszczególnych daninach w analizowanych latach.

Wykres 2. Struktura zaległości budżetowych w 2016 r.

Struktura zaległości budżetowych w 2016 roku (w \%)

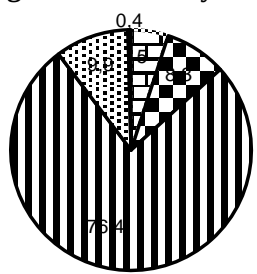

EPodatek dochodowy od osób prawnych

- Podatek dochodowy od osób fizycznych

口Podatek od towarów i usług

QPodatek akcyzowy

- Pozostałe

Źródło: Opracowane własne na podstawie danych tabeli 3. 
Z kolei szczególnie wysoką dynamiką przyrostu zaległości charakteryzował się podatek od towarów i usług (VAT), która w 2016 r. w stosunku do roku 2010 wyniosła 562,1\%, wysokie tempo dynamiki odnotować należy również w podatku dochodowym od osób prawnych -381,0\% (tabela 4). Z kolei dynamika w podatku dochodowym od osób fizycznych charakteryzowała się systematycznym, ale w miarę stabilnym przyrostem zaległości $(173,8 \%)$ w analizowanych okresie (średnioroczny przyrost zaległości 24,8\%). Jednym z istotnych skutków wzrostu poziomu zaległości w podatku VAT jest wysoki poziom jego stawek podatkowych. Wskazać należy, iż szczególnie niekorzystne dla gospodarki i społeczeństwa jest obciążanie tym podatkiem dóbr podstawowych.

Tabela 4. Dynamika zaległości budżetowych ogółem, w tym podatków dochodowych i podatków pośrednich w latach 2010-2016 (rok 2009 = 100\%).

\begin{tabular}{|l|r|r|r|r|r|r|r|}
\hline \multirow{2}{*}{ Wyszczególnienie } & \multicolumn{7}{|c|}{ Lata } \\
\cline { 2 - 8 } & $\mathbf{2 0 1 0}$ & $\mathbf{2 0 1 1}$ & $\mathbf{2 0 1 2}$ & $\mathbf{2 0 1 3}$ & $\mathbf{2 0 1 4}$ & $\mathbf{2 0 1 5}$ & $\mathbf{2 0 1 6}$ \\
\hline $\begin{array}{l}\text { Zaległości ogółem, } \\
\text { w tym: }\end{array}$ & 108,8 & 111,9 & 116,1 & 119,9 & 125,8 & 142,6 & 130,0 \\
\hline $\begin{array}{l}\text { podatek dochodowy } \\
\text { od osób prawnych }\end{array}$ & 98,8 & 113,0 & 101,7 & 147,4 & 116,3 & 131,6 & 147,0 \\
\hline $\begin{array}{l}\text { podatek dochodowy } \\
\text { od osób fizycznych }\end{array}$ & 109,4 & 111,2 & 117,2 & 113,1 & 107,0 & 105,5 & 104,4 \\
\hline $\begin{array}{l}\text { podatek od towarów } \\
\text { i usług }\end{array}$ & 108,3 & 114,6 & 123,3 & 127,8 & 141,9 & 155,2 & 141,2 \\
\hline podatek akcyzowy & 112,3 & 110,0 & 105,3 & 102,4 & 97,0 & 131,3 & 100,6 \\
\hline
\end{tabular}

Źródło: Opracowanie własne na podstawie danych tabeli 2.

Wzrost zaległości budżetowych w analizowanych latach wystąpił we wszystkich daninach publicznych. Tempo zaległości ogółem, w tym w podatku VAT, od roku 2014 było wyższe aniżeli w latach poprzednich. W marę stabilny przyrost zaległości charakterystyczny był dla podatku dochodowego od osób fizycznych. Wysoki przyrost zaległości nastąpił, w podatku od towarów i usług (powyżej 40\% rocznie, w 2015 - 55,2\%). Od 2011 r. był wyższy w stosunku do przyrostu zaległości ogółem (w 2011 r. 2,7 pkt proc.; w 2016 r. 11,2 pkt proc.). Związane to było w szczególności w tym tytule podatkowym z podjęciem działań w ramach 
tzw. optymalizacji podatkowej. Dynamikę zaległości podatkowych w latach 2010-2017 przedstawia wykres 3.

Wykres 3. Dynamika zaległości podatkowych w okresie 2010-2017 r.

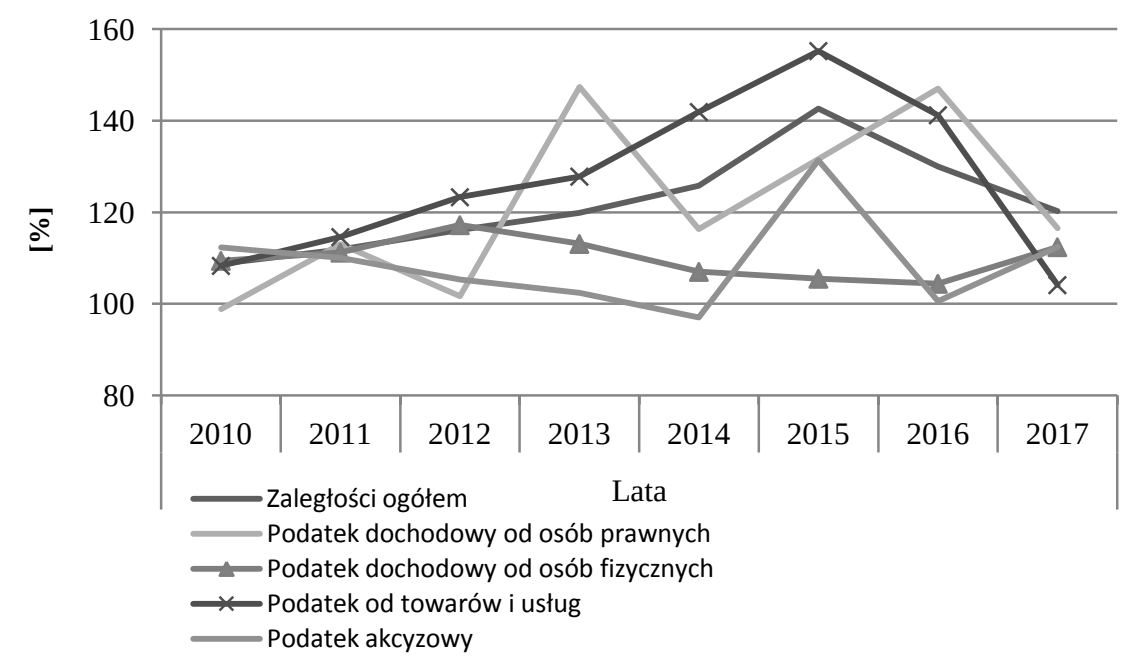

Źródło: Opracowane własne na podstawie danych tabeli 4.

Na stopień realizacji dochodów jednostek samorządu terytorialnego ma wpływ poziom zaległości budżetowych państwa oraz skuteczności ich ściągalności, w tym skala zaległości przedawnionych, które z różnych przyczyn nie mogły być wyegzekwowane od podmiotów zalegających przez organy administracji podatkowej ${ }^{11}$.

11 Zgodnie z ustawą z dnia 13 listopada 2003 r. o dochodach jednostek samorządu terytorialnego (tekst jedn. Dz.U. z 2018 r. poz. 1530 ze zm.) źródłem dochodów gminy jest wysokość udziału we wpływach z podatku dochodowego od osób fizycznych 39,34\%, w podatku dochodowym od osób prawnych - 6,71\% (art. 4 ust 3 i 4 ustawy); powiatu jest wysokość udziałów odpowiednio 10,25\% i 1,4\% (art. 5 ust. 2 i 3 ustawy) oraz województwa odpowiednio 1,60\% i 14,75\% (art. 6 ust. 2 i 3 ustawy). 


\section{Dochodzenie zaległości budżetowych ze względu na formę prowadzonego postępowania}

Dochodzenie zaległości budżetowych prowadzone jest na podstawie przepisów ustawy z dnia 17 czerwca 1966 r. o postępowaniu egzekucyjnym $\mathrm{w}$ administracji ${ }^{12}$ przez organ egzekucyjny, który uprawniony do stosowania w całości lub w części określonych w ustawie środków służących doprowadzeniu do wykonania przez zobowiązanych ich obowiązków o charakterze pieniężnym lub obowiązków o charakterze niepieniężnym oraz zabezpieczania wykonania tych obowiązków ${ }^{13}$. Wierzycielem podatkowym, na rzecz którego dokonywane jest świadczenie podatkowe w imieniu budżetu państwa, jest naczelnik urzędu skarbowego. Co do zasady jest on jednocześnie uprawniony do wdrożenia przymusowej realizacji tego świadczenia. W obecnym stanie prawnym dochodzenie należności budżetowych prowadzone jest przez naczelnika urzędu skarbowego oraz dyrektora izby celnej. Naczelnik urzędu skarbowego jest organem egzekucyjnym uprawnionym do stosowania wszystkich środków egzekucyjnych w egzekucji administracyjnej należności pieniężnych oraz do zabezpieczania takich należności, zaś dyrektor izby celnej jest organem egzekucyjnym uprawnionym do stosowania wszystkich środków egzekucyjnych, z wyjątkiem egzekucji z nieruchomości, w egzekucji administracyjnej należności pieniężnych, do których poboru zobowiązane są organy celne na podstawie odrębnych przepisów.

Właściwe postępowanie egzekucyjne poprzedzone jest działaniami komórki wierzycielskiej organu egzekucyjnego powołanej w 2014 r. w urzędach i izbach skarbowych, których zadaniem jest zarządzanie zaległościami, w tym wykonywanie czynności poprzedzających wszczęcie postępowania egzekucyjnego (w ramach tzw. miękkiej egzekucji), koordynowanie oceny i analizy ryzyka dotyczących braku wykonania zobowiązań podatkowych $\mathrm{w}$ wyniku ich przedawnienia oraz podejmowanie

12 Test jedn. Dz.U. z 2018 r., poz. 1314 ze zm.

13 D.R. Kijowski (red.), Ustawa o postępowaniu egzekucyjnym w administracji. Komentarz. 2. Wydanie, Warszawa 2015, s. 97. 
innych działań służących zabezpieczeniu i wykonaniu zobowiązań podatkowych w zakresie należącym do zadań innych komórek organizacyjnych).

„Miękka egzekucja” polega na działaniach informujących i dyscyplinujących poprzedzających wszczęcie postępowania egzekucyjnego, prowadzone w stosunku do podatników z zastosowaniem środków komunikacji bezpośredniej (telefon, sms, e-maile informujące o braku wpłat zobowiązania podatkowego) ma na celu doprowadzenie do zwiększenia dobrowolnego wykonania zobowiązania podatkowego bez stosowania przymusu egzekucyjnego, także poinformowanie o konsekwencji wynikających z nieuregulowania zobowiązania (kosztach przymusowego ściągnięcia zaległości).

$\mathrm{Z}$ danych tabeli 5 wynika, że postępowaniem egzekucyjnym w latach 2010-2016 objęto odpowiednio: 58,3\%, 56,1\%, 54,9\%, 55,8\% i 53,0\% zaległości budżetowych ogółem. Oznacza to, że w kolejnych latach wystąpiła tendencja obniżania poziomu zaległości budżetowych objętych postępowaniem egzekucyjnym (o 7,2 pkt proc.). Do negatywnych zjawisk należy zaliczyć wysoki poziom zaległości z lat ubiegłych. W analizowanym okresie wskaźnik udziału zaległości w egzekucji do zaległości ogółem kształtował odpowiednio: 69,8\%; 65,8\%; 66,9; 65,8\% i 66,2\%.

Za nieskuteczne należy uznać dochodzenie zaległości budżetowych objętych postępowaniem układowym i upadłościowym. W postępowaniach układowym budżet państwa ze względu na trudności finansowe podatnika w wielu przypadkach rezygnuje $\mathrm{z}$ ich dochodzenia. W postępowaniu upadłościowym syndyk w pierwszej kolejności z dochodów ze sprzedaży masy upadłości pokrywa koszty postępowania upadłościowego, w następnej kolejności wynagrodzenia byłych pracowników podmiotu upadłego.

Udział zaległości objętych postępowaniem układowym i postępowaniem upadłościowym w latach 2010-2014 kształtował średnio powyżej 13\%, tj.: 13,2\%; 12,8; 14,4\%; 14,1\%, zaś w latach 2015-2016 wskaźnik ten uległ obniżeniu do poziomu 6,4\% i 5,3\% zaległości ogółem (spadek 7,7 pkt proc.), wzrost o kwotę 1448,9 mln. Wzrost zaległości podatkowych, w szczególności w podatku od towarów i usług, w mniejszym stopniu wpłynął w stosunku do wzrost zaległości w postępowaniu układowym 
i upadłościowym (wzrost o 47,4\%). Spowodowane jest to głownie odmową przez sądy wszczęcia postępowań w związku z brakiem majątku podatnika (ucieczka z majątkiem).

Wysoki poziom tych zaległości ogranicza możliwość ich wyegzekwowania, angażuje aparat egzekucyjny do działań okresów minionych. Powodują one ograniczenia w funkcjonowaniu podmiotów gospodarczych wynikające z dodatkowych kosztów egzekucyjnych. Istotnym jednak dylematem takiego stanu jest obniżenie dochodów budżetowych zabezpieczających realizację zadań publicznych.

Tabela 5. Informacja o kształtowaniu się zaległości ze względu na formę prowadzonego postępowania w latach 2010-2016.

\begin{tabular}{|c|c|c|c|c|c|c|c|}
\hline \multirow{2}{*}{ Wyszczególnienie } & \multicolumn{7}{|c|}{ Lata } \\
\hline & 2010 & 2011 & 2012 & 2013 & 2014 & 2015 & 2016 \\
\hline $\begin{array}{l}\text { Zaległości ogółem, } \\
\text { w tym: }\end{array}$ & 23138,2 & 25895,0 & 30076,6 & 36078,6 & 45373,0 & 64712,5 & 85455,1 \\
\hline $\begin{array}{l}\text { zaległości z lat } \\
\text { ubiegłych }\end{array}$ & 16141,6 & 18183,1 & 20115,5 & 23895,3 & 29875,2 & 38587,3 & 56249,1 \\
\hline $\begin{array}{l}\text { płatne w ratach } \\
\text { i odroczone }{ }^{14} \text {, } \\
\text { w tym objęte } \\
\text { restrukturyzacją }\end{array}$ & $\begin{array}{r}375,1 \\
35,9\end{array}$ & $\begin{array}{r}428,5 \\
11,9\end{array}$ & $\begin{array}{r}426,9 \\
2,6\end{array}$ & 578,1 & $\begin{array}{r}712,4 \\
1,7\end{array}$ & $\begin{array}{r}888,0 \\
0,5\end{array}$ & 987,4 \\
\hline $\begin{array}{l}\text { wstrzymanie wyko- } \\
\text { nania decyzji }{ }^{15}\end{array}$ & 366,3 & 341,5 & 272,4 & 325,2 & 790,4 & 1056,6 & 2 018,1 \\
\hline $\begin{array}{l}\text { w postępowaniu } \\
\text { egzekucyjnym }^{16} \text {, } \\
\text { w tym zaległości } \\
\text { z lat ubiegłych }\end{array}$ & $\begin{array}{l}13486,5 \\
10026,4\end{array}$ & 10552,8 & $\begin{array}{l}16504,2 \\
11303,6\end{array}$ & 12863,3 & $\begin{array}{l}24064,8 \\
15412,7\end{array}$ & 20240,0 & $\begin{array}{l}43660,6 \\
30080,0\end{array}$ \\
\hline $\begin{array}{l}\text { Zaległości objęte } \\
\text { - } \quad \text { postępowaniem } \\
\text { układowym }\end{array}$ & 19,3 & 10,4 & 106,3 & 66,3 & 65,4 & 52,0 & 46,6 \\
\hline
\end{tabular}

\footnotetext{
14 Zaległości zarówno z lat ubiegłych, jak i bieżące.

15 Wstrzymanie wykonania decyzji w związku wniesieniem skargi do sądu administracyjnego (art. 239f Ordynacji podatkowej).

16 Zaległości zarówno z lat ubiegłych, jak i bieżące.
} 


\begin{tabular}{|l|r|r|r|r|r|r|r|}
$-\begin{array}{l}\text { postępowaniem } \\
\text { upadłościowym }\end{array}$ & 3034,1 & 3295,4 & 4230,1 & 5026,0 & 4744,3 & 4131,0 & 4455,7 \\
$-\begin{array}{l}\text { wynikające } \\
\text { z decyzji nieost. } \\
\text { w stosunku } \\
\text { do których nie } \\
\text { podjęto żadnych } \\
\text { czynności }\end{array}$ & 791,4 & 1374,7 & 1421,8 & 1246,8 & 1974,8 & 3203,6 & 4787,7 \\
$-\begin{array}{l}\text { pozostałe należ- } \\
\text { ności } \\
\text { należności wyni- } \\
\text { kające z decyzji } \\
\text { nieost. z rygorem } \\
\text { wykonalności }\end{array}$ & 4946,0 & 5759,3 & 6790,5 & 8515,7 & 12793,3 & 20341,3 & 27323,3 \\
\hline
\end{tabular}

Źródło: Opracowanie własne na podstawie danych Ministerstwa Finansów, Informacja o kształtowaniu się zaległości budżetowych za poszczególne lata. Za lata 2010-2016.

Z przeprowadzonej kontroli NIK w urzędach skarbowych wynika, że jest dość niska skuteczność egzekucji zaległości gmin. Wskaźnik skuteczności egzekucji mierzonej jako stosunek liczby tytułów załatwionych w danym roku (okresie) objętym kontrolą (w tym tytułów otrzymanych w latach poprzednich) do liczby tytułów otrzymanych w danym roku (okresie) objętym kontrolą, wynosił 33\% - w przypadku tytułów przekazanych przez prezydentów miast - oraz 40\% - w przypadku tytułów przekazanych przez innych wierzycieli ${ }^{19}$. Najwyższa Izba Kontroli zauważyła, że w roku 2013 również kształtował się niski poziom skuteczność egzekwowania zaległości podatkowych przez urzędy skarbowe. Wskaźnik

17 Raport roczny Coface: Upadłości i restrukturyzacje firm w Polsce w 2017 r., www.coface.gov. W roku 2017 liczba upadłości i restrukturyzacji polskich firm wyniosła 885, czyli o 16\% więcej niż w roku 2016 (wg danych na 28 grudnia 2017 r.). Wśród rodzajów postępowań najwięcej ogłoszono upadłości (537, tj. 61\%). Coraz częściej stosowane są postępowania restrukturyzacyjne, wprowadzone z początkiem 2016 r. wraz z nowym prawem upadłościowym. Ich udział we wszystkich postępowaniach rośnie - w 2017 r. wyniósł 39 proc., podczas gdy w 2016 r. stanowił 27\%. Decyzje niepodlegające wykonaniu (art. 239a Ordynacji podatkowej).

19 Najwyższa Izba Kontroli Delegatura w Kielcach, LKI-41014-08 Nr ewid. 161/2008/P/ 08/139/LKI Informacja o wynikach kontroli efektywności egzekucji administracyjnej podatków i opłat, dla których ustalania lub określania i pobierania właściwy jest organ gminy, maj $2009 \mathrm{r}$. 
skuteczności egzekucji wyniósł 23,0\%. Skuteczność egzekucji zaległości w VAT w 2013 r. obniżyła się z 26,8\% do 24,1\%, w CIT z 26,4\% do $22,5 \%{ }^{20}$.

Niska skuteczność egzekucji zaległości budżetowych, w tym skala zaległości przedawnionych w podatkach dochodowych, które z różnych przyczyn nie mogły być wyegzekwowane przez organy administracji podatkowej, ma wpływ na obniżenie poziom dochodów jednostek samorządu terytorialnego ${ }^{21}$.

Wprowadzono zmiany zmierzające do poprawy egzekwowania należności budżetowych. Zasadniczym działaniem w tym zakresie było uchwalenie ustawy o wzajemnej pomocy przy dochodzeniu podatków, ceł $\mathrm{i}$ innych należności pieniężnych ${ }^{22} \mathrm{w}$ związku $\mathrm{z}$ koniecznością wdrożenia dyrektywy Rady Unii Europejskiej ${ }^{23}$ oraz od 1 stycznia 2017 r. konsolidacja służb podatkowych i celnych oraz kontroli skarbowej w ramach Krajowej Administracji Skarbowej ${ }^{24}$. W wyniku wprowadzonych zmian przyjąć należy istotną poprawę skuteczności dochodzenia należności budżetu państwa.

20 Najwyższa Izba Kontroli, Analiza wykonania budżetu państwa i założeń polityki pieniężnej w 2013 roku, Nr ewid. 138/2014/KBF, 139/2014/KBF, druk sejmowy nr 2495, s. 98.

21 Obciążenia fiskalne - główne daniny publiczne, dające najwyższe dochody publiczne, podatki bezpośrednie (PIT, CIT, podatki od zysków kapitałowych), podatki pośrednie (VAT, akcyza) oraz składki na ubezpieczenia społeczne. Na dochody całego sektora finansów publicznych składają się w Polsce m.in. wpływy z ceł, dochody z majątku Skarbu Państwa, wpływy z zysku NBP, wpływy z opłaty skarbowej i administracyjnej, podatków od czynności cywilnoprawnych, od spadków i darowizn, od nieruchomości czy podatku rolnego i leśnego oraz od środków transportowych. Poza podatkami istotnym obciążeniem fiskalnym są składki na ubezpieczenia społeczne.

Dz.U. poz. 1289 ze zm.

23 Dyrektywa Rady 2010/24/UE z dnia 16 marca 2010 r. w sprawie pomocy przy odzyskiwaniu wierzytelności dotyczących podatków, ceł i innych obciążeń (Dz.Urz. UE L 84 z dnia 31 marca 2010, s. 1).

24 Ustawa z dnia 16 listopada 2016 r. o Krajowej Administracji Skarbowej oraz ustawa z dnia 16 listopada 2016 r., tekst jedn. Dz.U. z 2018 r., poz. 508 ze zm., - przepisy wprowadzające ustawę z dnia 16 listopada 2016 r. o Krajowej Administracji Skarbowej, tekst jedn. Dz.U. poz. 1948 - z dniem wejścia w życie o 1 stycznia 2017 r. 


\section{Wnioski końcowe}

Zagrożenie bezpieczeństwa finansowego państwa znajduje odzwierciedlenie w poziomie zaległości budżetowych. W latach 2010 i 2016 zaległości budżetowe wykazywały wysoki poziom wzrostu, szczególnie dotyczy to dynamiki w podatku od towarów i usług. Charakterystyczny dla tych lat jest również wzrost wydatków budżetowych oraz wzrost deficytu budżetu państwa w latach 2013-2014. Wysoki poziom zaległości budżetowych w sposób istotny wpłynął na obniżenie strumienia dochodów do budżetu państwa oraz budżetów jednostek samorządu terytorialnego. Przekłada się to na ograniczenie realizacji zadań publicznych przez państwo i jednostki samorządu terytorialnego, w konsekwencji obniżenia płynności finansowej.

Istotą VAT jest to, że jest znaczącym „wkładem” konsumenta do budżetu państwa poprzez konsumpcję opodatkowanych towarów i usług. Jednak wzrost dochodów budżetu państwa oraz wysoki wzrost poziomu zaległości budżetowych może świadczyć o nadmiernym fiskalizmie wyrażający się wysokością stawek podatkowych, poziomem obciążeń fiskalnych w stosunku do PKB (efekt Laffera - wadą jest jednak, iż poziom punktu optymalnego opodatkowania jest nieznany). Stan ten ma wpływ na ograniczenie aktywności gospodarczej i społecznej ${ }^{25}$. Świadczyć może też o wzmocnieniu dyscypliny budżetowej oraz wzrostu skuteczności działania organów administracji podatkowej w ściągalności danin publicznych.

Istnieją istotne trudności w egzekwowaniu danin publicznych, które narastają z każdym rokiem budżetowym. Nie należy pomijać wpływu na poziom wzrostu zaległości budżetowych skutków istnienia: szarej strefy, nadmiernego fiskalizmu, poziom stawek oraz ich zróżnicowanie w podatku od towarów i usług dla podobnych grup asortymentowych, a także niskiego ujawniania nieprawidłowości w systemie podatkowym. Podkreślić jednak należy dość niski poziom wskaźnika skuteczności egzekucji. Aparat egzekucyjny jest angażowany do ściągalności zaległych zobowią-

25 W Polsce zdarzały się sytuacje, w których ciężary fiskalne były przyczyna niepokojów społecznych, np. protestów publicznych w latach 90. XX w. w związku z podatkiem od ponadnormatywnych wynagrodzeń, czy ostatnio opodatkowaniem sklepów wielopowierzchniowych, w Wielkiej Brytanii w związku z ideą wprowadzenia podatku pogłównego. 
zań budżetowych. Odbywa się to kosztem obniżenia realizacji zadań bieżących i przy niższych ich efektach.

Koszty postępowań egzekucyjnych były również przedmiotem badań Europejskiego Centrum Doradztwa i Dokumentacji Podatkowej. Z przedstawionego w 2009 r. raportu wynika, że koszty administracyjne poboru podatków są w Polsce kilkakrotnie wyższe niż w najlepiej rozwiniętych krajach.

Egzekwowanie należności budżetowych po upływie terminu ich płatności powoduje znaczny ich wzrost z tytułu dodatkowych odsetek. Skutkuje to w wielu przypadkach upadłością podatnika. Z masy upadłościowej w pierwszej kolejności są zaliczane wpływy na rzecz postępowania upadłościowego kosztem zaspokojenia budżetu państwa z tytułu zaległych zobowiązań podatkowych. W postępowaniu układowym budżet państwa dość często zrzeka się dochodzonych zaległości (w 2016 r. postępowaniem układowym i upadłościowym objęte było 5,3\% zaległości ogółem) ${ }^{26}$. Z okazji stulecia odzyskania niepodległości rząd mógłby przedstawić projekt ustawy o amnestii podatkowej dla pewnej grupy podatników, np. posiadających zaległości wobec budżetu państwa powstałych z momentem ustalenia zobowiązania podatkowego, do kwoty do 50 tys. zł, niezabezpieczonych hipotecznie lub zastawem skarbowym w rozumieniu Ordynacji podatkowej.

Istotną pozycję stanowią zaległości nieobjęte postępowaniem egzekucyjnym (w 2016 r. nie podjęto żadnych czynności egzekucyjnych wobec 2,54\% zaległości ogółem). Spowodowane jest to głównie brakiem możliwości zajęcia korzyści majątkowych zobowiązanego przed wszczęciem postępowania podatkowego. W tej sytuacji prowadzenie postępowania egzekucyjnego $\mathrm{w}$ ramach skargi pauliańskiej jest procedurą dość złożoną z punktu prawnego i długotrwałą ${ }^{27}$.

26 Art. 270 ust 1 pkt 3 ustawy z dnia 28 lutego 2003 roku Prawo upadłościowe i naprawcze (tekst jedn. Dz.U. z 2017 r., poz. 2344 ze zm.).

27 Zob. W. Grześkiewicz, Komentarz do art. 62 ustawy o postępowaniu egzekucyjnym, [w:] D.R. Kijowski (red.), Ustawa o postępowaniu egzekucyjnym..., s. 595 i n.; E. Chylińska, F. Kalinowski, E. Maciejak, Skarga pauliańska a zobowiqzzania podatkowe, Helsińska Fundacja Praw Człowieka, „Analizy i Rekomendacje”, 2016, nr 3. 
Rozważenia wymaga problem przedawnienia należności podatkowych zabezpieczonych hipotecznie. Przepis art. $70 £ 8$ Ordynacji podatkowej stanowi, iż zobowiązania zabezpieczone hipoteką przymusową nie przedawniają się. Zastrzega się jednak, że po upływie terminu przedawnienia nie może być prowadzona egzekucja z innych składników majątku podatnika niż obciążona nieruchomość. Zasadność tego „przywileju” budzi jednak wątpliwości. Trybunał Konstytucyjny wyrokiem z dnia 8 października 2013 r., sygn. akt SK 40/12 ${ }^{28}$ uznał „za sprzeczne z ustawą zasadniczą nieprzedawnianie się zobowiązań podatkowych zabezpieczonych hipoteką przymusową. Naruszenie obowiązku płacenia podatku - mimo że jest zachowaniem nagannym i sprzecznym z interesem publicznym nie uzasadnia egzekwowania długu przez dziesięciolecia. Trybunał Konstytucyjny nie zanegował samej możliwości ustanowienia hipoteki przymusowej. Nie może być natomiast tak, że podatnicy posiadający grunt czy dom znajdują się w gorszej sytuacji niż ci, którzy takim majątkiem nie dysponują. Nie wolno uzależniać zakresu czasowego obowiązków obywateli i firm od tak arbitralnej przesłanki, jaką jest fakt posiadania lub nieposiadania nieruchomości”29.

\section{Bibliografia:}

Buchanan J.M., Finanse publiczne w warunkach demokracji, Wydawnictwo Naukowe PWN, Warszawa 1997.

Chylińska E., Kalinowski F., Maciejak E., Skarga pauliańska a zobowiq̨zania podatkowe, Helsińska Fundacja Praw Człowieka, „Analizy i Rekomendacje” 2016, nr 3, s. 1-12.

Fedorowicz Z., Finanse publiczne, [w:] J. Ostaszewski (red.), Finanse, Difin, Warszawa 2008.

Gaudemet P.M., Molinier J., Finanse publiczne, PWE, Warszawa 2000.

Kijowski D.R. (red.), Ustawa o postępowaniu egzekucyjnym w administracji. Komentarz, 2. Wydanie, Lex a Wolters Kluwer business, Warszawa 2015.

8 Dz.U. poz. 1313.

29 Zob. wyrok NSA z dnia 5 grudnia 2014 r., I FSK 1824/13, CBOSA, oraz wyrok NSA z dnia 21 stycznia 2015 r., II FSK 1764/14, CBOSA. 
Redo M., Wójtowicz K., Ciak J.M., Bezpieczeństwo finansów publicznych, CeDeWu, Warszawa 2018.

Ślifirczyk M., Ogólne materialne prawo podatkowe, [w:] M. Bitner, E. ChojnaDuch, M. Grzybowski, J. Chowaniec, P. Karwat, E. KornbergerSokołowska, M. Lachowicz, H. Litwińczuk, W. Modzelewski, K. Radzikowski, M. Supera-Markowska, M. Ślifirczyk, K. Tetłak, M. Waluga, Prawo finansowe. Prawo finansów publicznych. Prawo podatkowe. Prawo bankowe, Wolters Kluwer, Warszawa 2017.

Wierzba R., System gwarantowania depozytów jako element sieci bezpieczeństwa finansowego. Doświadczenia francuskie, „Bezpieczny Bank” 2005, nr 1, s. 38-56. 